\title{
Becoming reflective practitioners: Mathematics student teachers' experiences
}

\author{
Elizabeth Ndeukumwa Ngololo ${ }^{1}$, Leena Ngonyofi Kanandjebo ${ }^{2 *}$ \\ ${ }^{1}$ Multi-disciplinary Research Centre, University of Namibia, Namibia \\ ${ }^{2}$ Faculty of Education, University of Namibia, Namibia \\ Corresponding Author: lvilma204@gmail.com
}

ARTICLE INFO

Article history:

Received: 21 October 2020

Revised: 12 January 2021

Accepted: 14 January 2021

Published online: 26 March

2021

Published regularly: April 2021

Keywords:

Reflective practice, student

teachers,

Mathematics,

teacher training program

\section{ABSTRACT}

The level of quality reflective practice remains low among student teachers majoring in Mathematics education. This paper aims to identify the levels of reflective practice possessed by Mathematics education student teachers in a teacher training program at higher learning institutions in Namibia. The professional status requires that teachers become reflective practitioners to develop their effectiveness- a skill they can acquire during their training. A reflection framework was used to identify levels of reflective practices among Mathematics student teachers. This study is qualitative and employed a narrative inquiry approach to assess the effectiveness of reflective practice as experienced by student teachers. A total of ten third-year undergraduate students majoring in Mathematics Education participated in the study by generating reflective journals. The results show that student teachers have insufficient reflective skills which are limited to the first two levels of the reflection framework: technical reflection and reflection-in-andon-action. This could be due to little guidance offered on developing reflective skills and its use by student teachers. This study's findings will be used to improve the rationality, social and educational practices among the student teachers.

@ 2021 Universitas Muhammadiyah Surakarta

\section{Introduction}

Reflective practice (RP) and teachers becoming reflective practitioners are regarded as an essential professional attributes of teacher education globally (Aldahmash, Alshmrani \& Almufti, 2017; Connelly \& Clandinin, 2000; Harrison \& Lee, 2011; White, 2004). However, the nature of reflection and effective practitioners' development in teacher training programs in developing countries remains a concern. Reflective practice demands taking thoughtful steps to partake in learning daily and recognizing one's responsibility for one's lifelong learning; it is alsoc oncerned with the promotion of skills and competencies necessary for the development of general capabilities and specific performance of any given task (Chapman, 2012; Sibahi, 2015). Skills and competences developed through

To cite this article:

Ngololo, E. N., \& Kanandjebo, L. N. (2021). Becoming reflective practitioners: Mathematics student teachers' experiences. JRAMathEdu (Journal of Research and Advances in Mathematics Education), 6(2), 128-141. https://doi.org/10.23917/jramathedu.v6i2.12375 
training programs have a bearing on how well student teachers perform on their tasks and adapt their knowledge and competence to new tasks (Chapman, 2012). In an effort to improve professional competencies and assist in identifying personal strengths and relative limitations of student teachers, genuine reflection is imperative (Dotse, n.d). Through reflective practice, student teachers may have the opportunity to reflect on their teaching and learning events to improve classroom practices, assessment styles, lesson planning, and all components involved in the teaching and learning process. Thus, student teachers' skills, competence, and knowledge would be useful later on in their profession. Consequently, reflective practice allows student teachers to become skillful in making wellversed judgments and expert decisions about their teaching and ways of empowerment (Mathew, Mathew \& Peechattu, 2017; Robins, Ashbaker, Enriquez \& Morgan, 2003).

The practice of reflection is encouraged to improve teachers' education programs (Moore, 2004). Abovich (2016) noted that knowledge of the subject to be taught and how to teach it do not necessarily translate into becoming an effective teacher. Uzum and Berg (2014) urges teachers to be responsive to innovative practices to enhance their teaching practice capabilities. This can be achieved when teachers perform reflective actions in their teaching. Moreover, reflective practice is regarded as a highly sophisticated educational concept in the teaching and learning process (Khan, 2012), and efforts to implement it in teaching programs are extremely difficult to accomplish (Sleegers, Geijsel \& den Berg, 2012). On that note, teacher educators have argued for the introduction of research in areas of reflection in teacher education programs so that student teachers enter the profession with dispositions and skills that will enable them to learn from experience and become better at teaching throughout their careers (Gore \& Zeichner, 1991). In turn, teacher education is inextricably linked to teachers' lives and narrative inquiry studies (Craig, 2011).

Further, Craig calls for experiences to be told in narrative authority to reflect the knowledge generated over time and across contexts. The notion of reflective practice is not new in the Namibian education system. The institution of higher learning of interest advocates for reflective practice in teacher education programs (University of Namibia, 2020). Besides theory, student teachers at the same institution of higher learning are provided with a template with critical questions to guide reflection during their teacher training and practice. In addition, the Ministry of Education, through the National Institute for Educational Development (NIED) (2008), has included a component of reflection in the lesson preparation template; schools may modify the guidelines to fit their school environments. After graduation, student teachers may also influence reflective practices at schools where they are serving as teachers.

In post-colonial Namibia, teacher education was developed through a program known as the Integrated Teacher Training Programme (ITTP) funded by the Swedish International Development Agency (SIDA). The program aimed, amongst others, to prepare future teachers for social change in an independent Namibia. The ITTP adopted the four-guiding principle of accomplishing a critical and transformative pedagogy to achieve learner centeredness and democracy, integration and meaning, knowledge production, educational 
reflection, and critical constructivism (Dahlström, 2019). Further, Dahlström, stated that, from 1994 to 1996, the ITTP gave birth to the Basic Education Teacher Diploma (BETD). Through the BETD, teacher educators carried out practitioner inquiry through continuing professional development programs. Nyambe (1996) saw BETD as a conduit for a critical/transformative paradigm of teacher education, yet the system produced student teachers who lacked a critical approach to integrate a move towards re-defining transformative and active intellectuals. The status quo remained until the program was replaced with the Bachelors of Education program at the University of Namibia.

Researchers have noted with concern the teachers training program conducted in Namibia. O'Sullivan (2002) raised concerns about Reflective Practice (RP)'s appropriateness in a teacher training program at one of Namibia's higher learning institutions. Zeichner and Ndimande (2008) also contest the teacher training program noting that it imparts low-level skills to implement the prescribed curriculum and teaching methods. These contestations reflect the adaptation of misguided and inappropriate use/adoption of RP in Namibian teacher training program. However, a few instructors emphasised PR in their teaching approaches as it is left to their discretion to implement (Simasiku, 2013; Zeichner \& Ndimande, 2008).

Further, Zeichner and Ndimande (2008) claim that "sending student teachers out to schools with little guidance and support and merely telling them to reflect can be just as much a disservice to teachers and their pupils as efforts to train them to carry out teaching scripts mindlessly" (p.333). Therefore, this study aimed to determine the levels of reflective practice among student teachers specializing in Mathematics and how they experience the learning process of becoming reflective practitioners. Mathematics is one of the compulsory subjects in the Namibian school curriculum, and it is a pre-requisite to many prestigious courses at higher learning institutions in the country. Hence, teachers need a combination of skills above the level of content and pedagogical knowledge to be effective and efficient in teaching Mathematics (Nambira, 2016). Thus, the goal of becoming effective reflective practitioners can be achieved if Mathematics teachers have acquired the necessary skills and competencies during pre-service or in-service training programs and using RP (Craig, 2011). However, this article will strictly focus on Mathematics teachers' RP skills level during pre-service training.

This study is critical as studies on RP in Namibia have only focused on professional teachers' perceptions (Amukugo, Likando, Shakwa, \& Nyambe, 2010; Simasiku, Villet \& Kapenda, 2015) on the relationship between learner achievement and qualification and training and experience of a teacher at the senior primary phase (Nambira, 2016; Shaningwa, 2005). Hence, this study's primary objective is to identify the reflective practice levels of Mathematics student teachers. Valli's (1992) reflective levels and Gore and Zeichner (1991) analytical model are combined to help identify student teachers' competency levels concerning RP and subsequently propose areas of improvement.

\section{Literature review}

Various scholars have theorized the process of becoming reflective practitioners. These views provided a structure that generally guided the process of reflection. Jasper 
( $\underline{2013}$ ) developed a simple theory known as the Experience Reflection Action (ERA) cycle. According to Jasper, the reflection cycle begins with experiencing an event that is either bad or good, old or new, and also related to work or something else. After that, an individual is expected to reflect and take action which will result in another experience that is: 'What?', 'So what? 'Now, what?'. Driscoll believes that teachers should contextualize the situation/experience to present a clear understanding of the experience. Teachers are expected to reflect on their experience by asking 'so what?' concerning what is learned from an experience. They would then decide on the way(s) forward due to the reflection by either opting to change the behavior or persisting with the same practices.

Gore and Zeichner (1991) built reflective practice frameworks beyond Cruickshank's (1985) and Schon's (1983, 1987, 1991) frameworks. The authors focused on the significance of both the quality and type of reflection undertaken by individuals, the reflection content and the criteria considered (Sellars, 2017). Gore and Zeichner (1991) stressed the following: a) academic version, b) social efficacy version, c) developmental version, and d) social reconstructionist version as four 'varieties' of teacher reflective practice. These domains indicate four significant aspects of professional work (Sellars, 2017). In their own words, Gore and Zeichner (1991) argued that:

Neither Cruickshank (1985) nor Schon (1983, 1987, 1988) said much about what it is that teachers ought to be reflecting about, the kinds of criteria that should come into play during the process of reflection (e.g., what distinguishes good from unacceptable educational practice) and the degree to which teachers' deliberations should incorporate a critique of the institutional contexts in which they work (Richardson, 1990). In some extreme cases, the impression is given that as long as teachers reflect about something, in some manner, whatever they decide to do is acceptable, since they have reflected about it. (p. 120).

The academic domain focuses on teachers' reflection on their abilities to teach learning content in such a way so as to ease understanding for their learners maximally. The social efficacy domain emphasizes whether own teaching pedagogies and strategies are based on research findings and focuses on evidence-based practice that has proven to increase learners' academic success and meet learners' needs. The developmental domain primarily focuses on determining whether teaching strategies are appropriate for learners developmentally and whether they focus on learners' interests and thinking. Lastly, the social reconstructionist domain is regarded as a critical reflection (Gore \& Zeichner, 1991) in which reflection is focused on analyzing the political and social issues of schooling and classroom interactions. These aspects are used to promote more significant learner equity and justice.

Connelly and Clandinin (2001) emphasize teachers' knowledge, particularly as active agents required to produce knowledge from personal and social development perspectives. Teacher knowledge depicts image, rule practical principle, personal philosophy, metaphor, story unity, and rhythm. Pre-service teachers need to learn more about teacher knowledge by becoming self-conscious than the theories have learned in the academic teaching program. Hence the expectation that pre-service education should focus on what preservice teachers know and have found in professional practice (Clandinin \& Connelly, 2000). Craig (2011) stresses the need for these experiences be told in narrative authority representing a generative instead of a one-size-fits-all approach to teacher development 
because knowledge generated from experience over some time and across contexts is imperative. Thus, teacher knowledge through RP should promote the ability to think critically and scrutinize experience and integrate knowledge with self-improvement insight (Krishnamurthy, 2007). Furthermore, Krishnamurthy opines that RP should help to create understanding by making conscious decisions concerning professional, social and ethical assumptions, among other attributes, in order to correct mistakes, examine actions, evaluate them against prescribed norms, alter, repeat success and revise and plan continually (p. 14).

Various scholars have documented different levels of reflection in the teaching and learning process proposed based on time, process, level, and stage (Farrell, 2004; Lee, 2005; Schon, 1983; Valli, 1992,1997; Van Manen, 1977). Van Manen (1977) had developed three levels of reflection; these are: technical, practical, and critical reflection, based on the work of Habermas as a hierarchical structure (Sellars, 2017). The technical level is the lowest level of reflection in which the teacher considers the effectiveness of the practices to accomplish lesson goals and objectives (Alsuhaibani, 2019). The teacher reflects on context-specific teaching and learning at the practical level such as classroom experience, incidents, and specific students' actions. The critical level of reflection is the highest and incorporates the first two levels, but more positively, it considers moral and ethical considerations to support learners without personal bias. On one hand, in terms of time frames, Schön (1983), proposed concepts of reflection-on-action and reflection-in-action. Reflection-in-action happens while the action of teaching is taking place in the classroom. Reflection-on-action is teachers' reflection after teaching has occurred in the classroom.

On the other hand, Valli (1992) built on Schon's and Van Manen's frameworks to establish five reflection levels. These are: (a) technical reflection, similar to as described by Van Manen (1977), individuals at technical level match own competencies to professional standards, graduate competencies, the external goals and competencies of teaching amongst others. (b) The second level is reflection-in-and-on-action, a combination of the two domains that requires ongoing reframing, reconsideration, and self-discussion of the teaching process Schon (1983). Further, (c) at deliberative reflection level, teachers reflect on various viewpoints concerning pedagogical decision-making. The fourth level, (d) personalistic reflection, focuses on relationships with learners and personal growth in terms of emotions, intuitions, and self-knowledge towards learners and learning. The final level is (e) critical reflection which incorporates the development of open-mindedness, rational judgment, and creativity in the reflection process. In addition to the hierarchical levels of reflection, Lee $(\underline{2005})$ calls for consideration of alternative teaching and learning methods in line with future improvement.

Critical thinking, related to mathematical skills such as problem-solving, questioning and analysis, is an essential part of Mathematics education (Driscoll, 2015; Wahyudin, Ahman, Rusmono, Rahmawati, 2017). Reflection is not a practice in many Mathematics classrooms (Erdogan, 2019; Posthuma, 2012;). In an earlier study by Posthuma (2011), it was noted that Mathematics teachers have limited understanding of the concept of reflection and there was therefore no evidence that teachers reflect-for-action neither reflected on-action verbally or in writing. Furthermore, Posthuma (2011) found that at 
least three out of five teachers reflected-in-action while teaching. The researcher further found teachers who reflected at the critical level to be focused on learners' thinking about Mathematics and how their instruction might have influenced their understanding of Mathematics. However, Posthuma noted an increase in self-knowledge and found new ways of teaching Mathematics which lead to learners' acquisition of inquiry and problemsolving skills. This implies that after reflection, teachers were able to identify the skills gap in their teaching practices. Also, Driscoll (2015) narrated that the Mathematics teachers' reflection process and professional learning can lead to classroom practice changes such as promoting and sustaining conditions that further support student learning.

Notwithstanding, the teaching philosophy of individual lecturers determines the

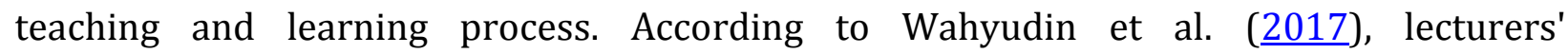
epistemological beliefs and openness to dispositions to engage student teachers to be aware of reflective practice's epistemic value are solely their responsibility. In that light, lecturers at an Indonesia-based university were found to keep updating teaching materials to include relevant reflective practice aspects as evidenced in their lesson plans, planning, and evaluation reports.

Cavanagh and Prescott (2010) used Lee's reflection levels to interpret interview responses of three beginning secondary Mathematics teachers. Their results showed that teachers developed a greater capacity for reflection in their first year of teaching. However, in their first year, student teachers did not demonstrate critical reflection. This is because it was possible that they did not possess the disposition to become reflective practitioners. Erdogan's (2020) findings on prospective middle school mathematics teachers' reflective thinking skills showed that prospective teachers' reflective thinking skill level is moderate (neutral) with an average score of 3.08. Lau (ㅁ18) examined the reflective practice of 22 pre-service Mathematics teachers (PMTs). The results indicated that the PMTs mostly focused on content reflection followed by process reflection. Lau noted that relatively few PMTs engaged in premise reflection.

Considering the studies in Namibia on reflective practice as implemented in universities' teaching programs, it was noted that the skills acquired are deficient and limited to technical skills. However, reflective practice discourse includes various concepts aimed to demonstrate self-consciousness and reflection, the practice of tacit and tactic knowledge (academic), and social reconstruction among other factors to build a more skilled teachers' workforce. This study focuses on describing the different levels of reflective practices through experiences a group of Mathematics student teachers' over a period of a minimum of three years in the teaching program.

\section{Research Methods}

The study is qualitative using an action research approach and self-reflective narrative inquiry by participants. Further, a criterion sampling method was used to select information-rich cases from individual students by recording their experiences in the following domains: rationality, social and educational practices. Selected participants were in their third year of undergraduate studies, studying towards an honors degree in 
Education, with Mathematics as one of the subjects of specializations at the target institution of higher learning. Further, participants had completed Phase 2 of their teaching practice during which they teach and observe experienced teachers' lessons. To obtain more information of the student teachers' experiences, 10 (ten) members of the Teaching Methods of Mathematics class (Cohen, Manion \& Morrison, 2007) were sampled.

Initially, the students had been taught a course, Teaching Methods of Mathematics, covering teaching strategies as the primary focus. The taught strategies include different types and levels of reflection. After Teaching Practice Phase 2, student teachers had completed reflective journals as per the course requirements and the journals were submitted together with their lesson plans. Furthermore, students were required to provide narratives of their teaching practice experiences as per Gore and Zeichner (1991) guidelines with reference to school, social efficacy, and development. By using narratives, the researchers embraced the view that writing is a method of inquiry- a way of knowing, and a discovery method (Richardson, 2000) thereby reflecting on student teachers teaching practices.

Transcripts were analyzed using a case-cross data analysis approach considering similarities and differences found at different levels of reflection and progress in developing quality reflective practice during the teaching program. The popular reflection type among student teachers denoted the five-level respected categories. Also, we selected certain events in order to hear multiple voices. Clandinin and Connely (2001) emphasize that we need to see student teachers as univocal and not tied to one theoretical structure that will make them appear uni-dimensional, considering representation and meaningmaking text to reflect student teachers' experiences. Thus, a comparison was drawn by way of significant divergence or similarities (Cohen, Manion, \& Morrison, 2007) to present a crystallized prologue to recognize life worlds' diversity and shared reasoning. Ethical approval was sought and obtained from the University of Namibia's Ethical Clearance Committee. In addition, consent was sought and obtained from the student teachers who participated in the study. All participants were reassured of confidentiality and anonymity in reporting the results and that they could withdraw their participation from the study at any time without penalty.

\section{Results and Discussion}

This section presents the results of student teachers' reflective journals. Examples from journal entries are presented as evidence of noteworthy incidences in line with the identified levels. All names used are pseudonyms and addressed as Student Teacher (ST)hence forth, ST1; ST2; ST3.

Generally, descriptive entries by student teachers varied due to the difference in total journal entries submitted. Even though each participant was encouraged to email one reflective teaching journal at the end of the course, a week after their teaching practice, not all participants had returned the questionnaires duly. The students cited reasons such as lack of time, preparation of lesson plans, and assignments that were due during data collection. 
The results show that student teachers focused on technical reflection and reflectionin-and-on-action level by stating how well the teaching methodology course and other related modules were conducted. Student Teacher 1 recounted:

It [the course] has prepared me very well in the sense that most of the content I have covered through various Math major modules... On the aspect of pedagogical strategies accommodative learners need, Inclusive Education has taught me a lot about the diversity of learners, and it's my obligation as an educator to accommodate all learners irrespective of their differences. Assessment and Evaluation has equipped me with various ways on assessment strategies which I have to use.

ST2 recounts:

... Teaching Methodology, together with other related modules, have helped me practically and cognitively. Being lectured how to manage your classroom, guiding and counseling learners, implying all characteristics of being a teacher, all strategies of teaching, rules and regulations in the teaching profession, creativity solving problems as well as doing presentations have helped/prepared me better in teaching Mathematics in secondary phase.

In addition, ST9 recalls:

The teaching methodology modules have made a big improvement to my experience as a Math student teacher. I thought teaching Mathematics was just a simple task that I will just stand and start doing, but I actually realized that is something that involves a lot of planning, skills and creativity as well. I have been taught a lot of teaching strategies that I'm going to use in my teaching. At the moment, I am now able to come up with a lesson plan. However, apart from teaching strategies, I also learned different assessment strategies and assessing learners. The important thing I have learned is that learners are not the same, and they do not have the same learning strategies; that is why I have to vary my teaching to accommodate all the learners' needs.

However, ST5 had a fairly different experience regarding acquisition of the necessary skills.

However, on the aspect of innovation and creativity, I feel like I am not fully equipped. More emphasis has to be placed in these two concepts. Yes, lecturers do talk about it, but they don't go deeper into it. They need to guide us into it; give us examples just to open up our minds

In essence, student teachers expressed technical reflection in their journals as they matched their own competencies to teaching professional standards. Some student teachers were aware of the need to reflect in line with specific teaching strategies needed to increase learners' academic success. For example, ST4 recalls,

I discovered that using a learner-centered approach is best; you engage them in a discussion to promote participation and critical thinking skills. As a result, about $80 \%$ of the class grasped the concept [not mentioned] in which almost everyone performed very well, and a few managed to go half way although they missed the final steps to the answer.

In another entry ST5 noted the following:

During Phase Two of teaching practices, I have picked up a few things that prove essential in subject delivery. For example, these are after class tutorials for learners, discussion during classes, and allowing learners to express themselves freely in class. Things that have proven to increase academic success are extra classes and exposing learners to real-world mathematical situations such as taking them to banks when dealing, for example, on money and finance. 
Contrary to the two reflections, ST9 expressed insufficient skills acquired over time as follows:

No, I did not yet pick up enough teaching skills during my teaching practice because as a teacher, you remain a learner for life. Some of the skills I will discover as I go on with the process of teaching as long as I remain reflecting on my own work that is when I will realize what I am supposed to and what I am not supposed to; therefore, I am still in the process of discovering more skills.

The critical reflection level required incorporating the development of openmindedness, rational judgment, and creativity in the reflection process. However, these characteristics lack in the entries as evidenced below:

ST4: Implementing what one has been taught can be a challenge since apart from dealing with the intellectual part, you are dealing with different kinds of behavior which can be quite challenging and might hinder the learning process if not handled accordingly. The behavioral approach we learned was shallow due to time. I had created a friendly environment with handouts to help learners get in the learning atmosphere as some believed that math is a complicated subject. I also tried to give them short motivational speech in class.

ST1: The purpose and functions of teaching Mathematics in Namibian schools is to develop thinking skills in school learners in order for them to use those skills to the benefit of their communities and societies. People do use Math in their daily life activities, and mathematics teaching provides them with the necessary techniques required. It also helps learners take carefully calculated and wise decisions in their future especially when it comes to purchasing items; the topic of money and finance plays a vital role.

ST7: I feel that the curriculum was supposed to accommodate slow learners by offering them a different curriculum in the old curriculum. I think that the only best way to minimize any disadvantage to particular groups of learners is by creating extra time to teach the slow learners in order for them to catch up with others.

Students have demonstrated insufficient reflective skills which are limited to the first two levels of the RP model. At the technical level, individual student teachers matched their competencies to professional standards and concentrated on teaching amongst other tasks. At the second level, a combination of constant engagement with reflection-in-action and reflection-on-action was noted demonstrating the capacity to teach. However, a skills gap was identified in terms of reframing and reconsidering the teaching process. This finding is in line with Posthuma (2011) and Driscoll (2015) who noted an increase in self-knowledge and emphasized new teaching methods to learners to enhance classroom practice. However, the need to support appropriate learning mechanisms was noted due to insufficient teaching materials at the university.

Student teachers seemed to have combined the constant engagement with reflectionin-action and reflection-on-action domains by stressing the need for ongoing learning. Acquiring the two domains requires student teachers to reconsider their efforts towards enhancing learner performance through active participation in numerous leaning processes and exposing them to real-life situations. This makes Mathematics relevant to real-life situations and enhances critical thinking. It can therefore be deduced that student teachers have demonstrated self-discussion of the teaching process. The excerpts at level two are reflected in Clandinin and Connely (2001) for student teachers' experiences to demonstrate diverse views and representations culminating into meaning-making. The third and fourth levels of Valli (1997) had few entries showing deliberative and 
personalistic reflections accordingly. However, this is not surprising as Erdogan ( $\underline{2020}$ ) and Lau (2018) found that student teachers did not possess the disposition to become reflective practitioners.

Student teachers noted that the skills acquired during the teaching program needed an upgrade in classroom management to create a conducive environment for learningmore so for slow learners. In addition, student teachers reflected more on the curriculum's content concerning what could be more appropriate for teaching to contribute to national development. This finding is similar to Lau (2018) who concluded that student teachers mostly focused on content reflection followed by process reflection and less on rational judgment and critical thinking. A few alternative ways of teaching and learning were

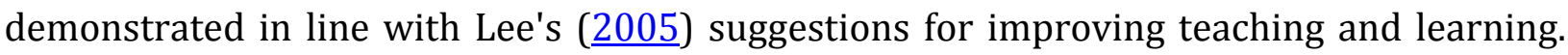
Suggestions for improvements of teaching and learning are necessary so that student teachers that exit the teacher training program do not lack a critical approach to integrate a move towards re-defining transformative and active intellectuals (Nyambe,1996). Also, teaching competencies are based on reflective practices, subject knowledge, attitude, experience and values. Failure to acquire these skills will have detrimental effects on the quality of Mathematics teachers serving in Namibian schools.

\section{Conclusion}

This study concludes that most student teachers reflected at a technical level as they matched their competencies to professional teaching standards. Some student teachers demonstrated the need to reflect in line with specific teaching strategies needed to increase learners' academic success- illustrating the teaching process' self-discussion. However, skills necessary for the third and fourth level of Valli (1997) were negated. This could be attributed to lack of disposition to become reflective practitioners. There is a need to enhance teaching mechanisms that will generate open-mindedness, rational judgment, and creativity. The study further suggests a need to strengthen and avail opportunities that would promote and intensify reflective practices in the teacher training program at the University of Namibia.

\section{Acknowledgment}

We acknowledge the participants who availed their time to feedback and complete the research instruments.

\section{Bibliography}

Abovich, R. R. (2016). Reflective practice: A case study of four pre-service teachers of English (Master's thesis, Universidad Andrés Bello, Chile). Retrieved from http://repositorio.unab.cl/xmlui/handle/ria/13219

Aldahmash, A. H., Alshmrani, S. M., \& Almufti, A. N. (2017). Secondary school science teachers' views about their reflective practices. Journal of Teacher Education for Sustainability, 19(1), 43-53. https://doi.org/10.1515/ites-2017-0003 
Alsuhaibani, Z. (2019). Perceptions and practices of EFL pre-service teachers about reflective teaching. Arab World English Journal, 10(4), 62-73. https://doi.org/10.24093/awej/vol10no4.5

Amukugo, E. M., Likando, G. N., Shakwa, G. N., \& Nyambe, J. (2010). A critical review of teacher education in Namibia. In K. G. Karras \& C. C. Wolhuter. (Eds.). International Handbook on Teacher Education Worldwide: Issues and Challenges for teacher education. Athens: Atrapos editions, 805-822.

Cavanagh, M. \& Prescott, A. (2010). The growth of reflective practice among three beginning secondary Mathematics teachers. Asia-Pacific Journal of Teacher Education, 38 (2), 147-159. https://doi.org/10.1080/13598661003678968

Chapman, J. (2012). A new agenda for a new society. In K. Leithwood, J. Chapman, D. Corson, P. Hallinger, and A. Hart (Eds.), International Handbook of Educational Leadership and Administration. Dordrecht/Boston/London: Kluwer Academic Publishers.

Clandinin, D. J, \& Connelly, F. M. (2000). Narrative inquiry: Experience and story in qualitative research. San Francisco: Jossey-Bass.

Cohen, L., Manion, L., \& Morrison, K. (2007). Research methods in Education (6th ed.). London and New York, NY: Routledge Falmer.

Connelly, F.M. \& Clandinin, D. J. (2001). Exploring the landscape of Canadian teacher education. Asia-Pacific Journal of Teacher Education and Development, 4(1), 1-12.

Craig, C. J. (2011). Narrative inquiries into curriculum making in teacher education, Advances in Research on Teaching, 13, 19-42. https://doi.org/10.1108/S14793687(2011)00000130005

Cruickshank, D. (1985). Uses and benefits of reflective teaching. The Phi Delta Kappa, 66(10), 704-706. Retrieved from http://www.jstor.org/stable/20387492

Dahlström, L. (2019). Toward learner-centered and democratic teacher education. In Democratic teacher education reform in Africa, 47-63. Routledge.

Driscoll, J. (ed.). (2007). Practicing clinical supervision: A reflective approach for healthcare professionals. Edinburgh: Elsevier

Driscoll, K. (2015). Improving the effectiveness of mathematics teaching through active reflection. In M. Marshman, V. Geiger, \& A. Bennison (Eds.), Proceedings of the 38th Annual Conference of the Mathematics Education Research Group of Australasia (pp. 205-212). Sunshine Coast, QLD: MERGA. Retrieved from https://files.eric.ed.gov/fulltext/ED572435.pdf

Erdogan, F. (2019). Effect of cooperative learning supported by reflective thinking activities on students' critical thinking skills. Eurasian Journal of Educational Research, 80, 89112. https://doi.org/10.14689/ejer.2019.80.5

Erdogan, F. (2020). The relationship between prospective middle school mathematics teachers' critical thinking skills and reflective thinking skills. Participatory Educational Research, 7 (1), 220-241. https://doi.org/10.17275/per.20.13.7.1

Farrell, T. S. (2004). Reflective practice in action: 80 reflection breaks for busy teachers. Thousand Oaks, CA: Corwin Press.

Fleck, R. \& Fitzpatrick, G. (2010). Reflecting on reflection: Framing a design landscape. In Proceedings of OZCHI 2010. ACM, New York, pp 216-223. Retrieved from https://publik.tuwien.ac.at/files/PubDat 192739.pdf

Gibbs, G. (1998). Learning by doing: A guide to teaching and learning methods. Oxford: Further Education Unit, Oxford Polytechnic. 
Gore, J. \& Zeichner, K. (1991). Action research and reflective teaching in pre-service teacher education: A case study from the United States. Teaching and Teacher Education,7. 119-136. https://doi.org/10.1016/0742-05191)90022-H.

Harrison, J. K. \& Lee, R. (2011). Exploring the use of critical incident analysis and the professional learning conversation in an initial teacher education program. Journal of $\begin{array}{llll}\text { Education } & \text { for } & \text { Teaching, } & \text { 37(2), }\end{array}$ https://doi.org/10.1080/02607476.2011.558285.

Jasper, M. (2013). Beginning reflective practice. Andover: Cengage Learning.

Khan, M. I. (2012). Reflection as a teacher education concept, connotation and implementation: a qualitative case study of a Postgraduate Certificate in Education (Secondary) Programme at a UK university. [Doctoral dissertation, University of Leicester].

Retrieved

from https://ethos.bl.uk/OrderDetails.do?uin=uk.bl.ethos.558007

Kihlgren, P., Spanager, L., \& Dieckmann, P. (2014). Investigating novice doctors' reflections in debriefings after simulation scenarios. Medical Teacher 1-7. http://dx.doi.org/10.3109/0142159X.2014.956054

Kolb, D. (1984). Experiential learning: Experience as the source of learning and development. Upper Saddle River: Prentice Hall.

Krishnamurthy, S. (2007). Reflexive inquiry and reflective practice: Critical reflection and pedagogy in English language teaching. Nawa Journal of Communication, 1(2), 14-22. Retrieved from http://ir.nust.na/jspui/handle/10628/16

Lau, W.W.F. (2018). Reflective practice of pre-service mathematics teachers in an asynchronous online discussion forum. In T. Bastiaens, J. Van Braak, M. Brown, L. Cantoni, M. Castro, R. Christensen, G. Davidson-Shivers, K. DePryck, M. Ebner, M. Fominykh, C. Fulford, S. Hatzipanagos, G. Knezek, K. Kreijns, G. Marks, E. Sointu, E. Korsgaard Sorensen, J. Viteli, J. Voogt, P. Weber, E. Weippl \& O. Zawacki-Richter (Eds.), Proceedings of EdMedia: World Conference on Educational Media and Technology (pp. 643-647). Amsterdam, Netherlands: Association for the Advancement $\begin{array}{llll}\text { of } & \text { Computing } & \text { (AACE). Retrieved from }\end{array}$ https://www.learntechlib.org/primary/p/184255.

Lee, H. (2005). Understanding and assessing pre-service teachers' reflective thinking. Teaching and Teacher 21, 699715. https://doi.org/10.1016/i.tate.2005.05.007

Mathew, P., Mathew, P. \& Peechattu, P.J. (2017). Reflective practices: A means to teacher development. Asia Pacific Journal of Contemporary Education and Communication Technology (APJCECT), 3(1). Retrieved from https://apiar.org.au/wpcontent/uploads/2017/02/13 APJCECT Feb BRR798 EDU-126-131.pdf

Moore, A. (2004). The good teacher: Dominant discourses in teaching and teacher education. London: Routledge Falmer.

Nambira, G. (2015). Analyzing the determinants of teachers' mathematics teaching competencies in upper primary phase: Evidence from Namibia. International Journal of Innovation and Economic Development, 2,35-47. https://doi.org/10.18775/ijied.1849-7551-7020.2015.24.2004

National Institute for Educational Development (NIED). (2008). The national mathematics subject policy guide grades 5-12. Okahandja Namibia. http://www.nied.edu.na

Nyambe, K. J. (1996). Teacher education and societal transformation in post-apartheid Namibia: The limits and possibilities of the basic education teacher diploma program. https://doi.org/10.7939/R36Q1SS43 
O'Sullivan, M. C. (2002). Reform implementation and the realities within which teachers work: A Namibian case study. Compare: A Journal of Comparative and International Education, 32(2), 219-237. https://doi.org/10.1080/03057920220143192

Posthuma, A. (2011). The nature of mathematics teachers' reflective practice. Published Doctoral thesis. University of Pretoria. Johannesburg. Retrieved from https://repository.up.ac.za/handle/2263/24143

Posthuma, A. (2012). Mathematics teachers' reflective practice within the context of $\begin{array}{llll}\text { adapted } & \text { lesson } & \text { study. }\end{array}$ https://doi.org/10.4102/pythagoras.v33i3.140.

Richardson, V. (1990). The evolution of reflective teaching and teacher-education. New York: Teachers College Press.

Robins, A., Ashbaker, B., Enriquez, J. \& Morgan, J. (2003). Learning to reflect: Professional practice for professionals and paraprofessionals. International Journal of Learning, 10, 2555-2565.

Schön, D. (1983). The reflective practitioner: How professionals think in action. New York: Basic Books.

Schon, D. (1987). Educating the reflective practitioner. San Francisco: Jossey Bass.

Schon, D. (1991).The reflective practitioner: How professionals think and act. Oxford: Avebury.

Schön, D. A. (1988). From technical rationality to reflection-in-action. Professional judgment: A reader in clinical decision making, 60-77.

Sellars, M. (2017). Reflective practice for teachers. Los Angeles: SAGE. Retrieved from https://uk.sagepub.com/sites/default/files/upm-binaries/59229 Sellars.pdf

Shaningwa, L.M. (2005). The relationship between learner achievement and qualification, training and experience of grade 6 teachers in Namibia. Research Paper submitted partial fulfillment of the requirement of the SACMEQ Research Conference. Namibia.

Sibahi, R. (2015). Exploring reflective practice among college EFL teachers in Saudi Arabia. Arab World English Journal (AWEJ), 6(2), 337 - 351.

Simasiku, E.L. (2013). Teachers' perceptions on reflective practice in teaching at Dawid Bezuidenhout High School (Unpublished Master's Thesis). University of Namibia, Namibia.

Sleegers, P., Geijsel, F.,\& van den Berg, R. (2012). In K. Leithwood, J. Chapman, D. Corson, P. Hallinger, and A. Hart (Eds.). International Handbook of Educational Leadership and Administration. Dordrecht/Boston/London: Kluwer Academic Publishers.

University of Cambridge. (2020). Reflective practice toolkit. https://libguides.cam.ac.uk/reflectivepracticetoolkit/models

University of Namibia. (2020). Prospectus: Faculty of Education. Retrieved from https://www.unam.edu.na/sites/default/files/newsletter/education faculty prospec tus 2020.pdf

Uzum, B., Petrón, M., \& Berg, H. (2014). Pre-service teachers' first foray into the ESL classroom: Reflective practice in a service-learning project. TESL-EJ, 18(3).

Valli, L. (1992). Reflective teacher education. Albany, NY: State University of New York Press.

Valli, L. (1997). Listening to other voices: A description of teacher reflection in the United $\begin{array}{llll}\text { States. Peabody Journal of } & \text { Education, }\end{array}$ https://doi.org/10.1207/s15327930pje72014

Van Manen, M. (1977). Linking ways of knowing within ways of being practical. Curriculum Inquiry, 6,205-228. https://doi.org/10.1080/03626784.1977.11075533 
Wahyudin, D., Ahman, Rusmono, D., \& Rahmawati, Y. (2017). Teaching philosophy of selected teacher education institutions in Indonesia. International Journal of Technical Research and Application, 5(4), 67-78.

White, D. (2004). Reflective practice: Wishful thinking or a practical leadership tool? Practising Administrator, 26 (3): 41-44.

Zeichner, K \& Ndimande, B. (2008). Contradictions and tensions in the place of teachers in educational reform: Reflections on teacher preparation in the USA and Namibia. Teachers and Teaching, $14(4)$ 331-343. https://doi.org/10.1080/13540600802037751 